\title{
Асоціація поліморфізму генів BCL-2, CTLA-4, APO-1/Fas з активністю проліферації й апоптозу в тиреоїдній тканині хворих із вузловими формами зоба на тлі автоімунного тиреоїдиту та аденоми щитоподібдної залози
}
M.І. Шеремет ${ }^{1}$, Л.П. Сидорчук ${ }^{1}$, В.О. Шідловський², О.В. Шідловський², А.Д. Беденюк ${ }^{2}$, Г.С. Курочкин ${ }^{3}$, Н.П. Ткачук ${ }^{1}$, Я.В. Гирла'

${ }^{1}$ Буковинський державний медичний університет, м. Чернівці, Україна

${ }^{2}$ Тернопільський державний медичний університет ім. І.Я. Горбачевського, м. Тернопіль, Україна ${ }^{3}$ Державний університет медицини та фармації ім. М. Тестеміцану, м. Кишинів, Республіка Молдова

Резюме. Мета - вивчення показників апоптозу та проліферативної активності в тканині щитоподібної залози (ЩЗ) у хворих на вузловий зоб на тлі автоімунного тиреоїдиту (BЗАІT) та аденому ЩЗ (АЩЗ) порівняно з морфологічно незміненою тканиною, підрахунок кількості імунореактивних клітин, які експресують зазначені маркери. Матеріал і методи. Проводили порівняльний аналіз процесів апоптозу та проліферації в тканині ЩЗ у хворих на BЗАІT та АЩЗ і в морфологічно незміненій тканині Щ3 шляхом дослідження експресії/ щільності маркерів Fas/FasL, Bcl-2, p53 і Ki-67 на тиреоцитах у ділянках лімфоїдної інфільтрації та їх деструкції, а також у морфологічно незмінених ділянках тиреоїдної тканини (контроль). Підраховували кількість імунореактивних клітин, які експресують зазначені маркери, з використанням імуногістохімічного методу з урахуванням поліморфізму генів BCL-2 (rs17759659), CTLA-4 (rs231775) і APO-1/Fas (rs2234767). Результати. Встановлено,

\footnotetext{
* Адреса для листування (Correspondence): Буковинський державний медичний

університет, Театральна площа, 2, м. Тернопіль, 58000, Україна.

E-mail: zdovado@ukr.net

(с) М.І. Шеремет, Л.П. Сидорчук, В.О. Шідловський, О.В. Шідловський,

А.Д. Беденюк, Г.С. Курочкин, Н.П. Ткачук, Я.В. Гирла
} 
що у хворих на BЗАІТ та АЩЗ активуються декілька ланок програмованого кілінгу тиреоцитів із перевагою Fas-індукованого апоптозу, який асоціюється з промотором гена $B C L-2$ (rs17759659) ( $F=25,33 ; p<0,001)$ і майже у 6 разів слабше - з промотором гена CTLA-4 (rs231775) ( $F=4,23 ; p=0,017)$ через виражену експресію Fas i FasL на поверхні клітин у ділянках лімфоїдної інфільтрації та деструкції тиреоцитів (сильніше в носіїв GG-генотипу гена BCL-2 — на 18,54\% і 36,18\% відповідно), що свідчить про ініціацію зовнішнього шляху апоптозу через каспазний механізм (ефекторну каспазу 8).

Ключові слова: вузловий зоб на тлі автоімунного тиреоїдиту, аденома щитоподібної залози, поліморфізми APO-1/Fas, CTLA-4 і BCL-2 генів.

Захворюваність на автоімунний тиреоїдит (AIT) із кожним роком зростає, наступними роками очікується збереження цієї тенденції [1-5]. Дедалі частіше після операцій на щитоподібній залозі (ЩЗ) із приводу вузлів ставиться діагноз BЗАIT [6-9]. Разом із цим зростає число не цілком обгрунтованих операцій на залозі, причиною яких є псевдовузли або підозра на злоякісну трансформацію тканини у вузли. Все це пов'язано з труднощами діагностики самого AIT і вузлів на його тлі на передопераційному етапі. Супутній AIT значно ускладнює діагностику вузлового зоба.

Одним із механізмів пухлинної трансформації та прогресії є порушення регуляції клітинного циклу з пригніченням апоптозу та активацією проліферації. Перспективним внутрішньоклітинним маркером проліферації є білок Кі-67, антитіла до якого розпізнають ДНК-зв'язаний ядерний протеїн, присутній в ядрах клітин у 01-, 8-, 02- і М-фазах і відсутній у 00-фазі [3, 7-9]. Діагностично значущмим онкомаркером є білок р53 - продукт гена-супресора пухлини р53, експресується в усіх клітинах організму, активується після ушкоджень генетичного апарату, а також стимулами, які можуть призвести до подібних пошкоджень, або є сигналом за несприятливого стану клітини (стресу). Результатом його активації є зупинка клітинного циклу та реплікації ДНК, а за надмірного стресового сигналу - запуск апоптозу. Функція антиапоптичного білка р53 полягає у видаленні з пулу тих клітин, які є потенційно онкогенними. Майже в 50\% випадків злоякісних пухлин людини, у тому числі й ЩЗ, діагностують втрату функції білка р53 [10, 11, 15].

Смерть клітин опосередковується також системою взаємодії поверхневих клітинних рецепторів Fas/Fas ліганди або CD95L (II тип трансмембранного протеїну, що належить до сімейства чинника некрозу пухлин альфа (TNF), який експресується на цитотоксичних Т-лімфоцитах) й активується через каспазний механізм запуску апоптозу. Це є важлива ланка патологічного процесу для підтримки гомеостазу клітин імунної системи та імуно-захисних сил організму. Апоптоз через систему Fas/FasL $є$ також важливим шляхом власне знищення цитотоксичних Т-клітин [12-15].

Крім того, дослідженнями останніх років доведено, що генетичні мутації, надто регуляторних генів, спричиняють розвиток тиреопатій, у тому числі й BЗАIT $[16,17]$. Важливу роль у розвитку ВКЗАІТ відіграє поліморфізм генів інгібіторів активації Т-лімфоцитів CTLA-4 (Cytotoxic T-lymphocyte-associated-protein 4) i PTPN22 (Protein tyrosine phosphatase, nonreceptor type 22) [18-22]. Описано мутації в інших генах, які впливають на функцію лімфоїдної тканини ЩЗ або апоптоз, у т.ч. тиреоцитів: ген регулятора апоптозу $B C L-2$ (B-cell lymphoma 2) (rs17759659), APO-1/Fas (apoptosis antigen $1 /$ cluster of differentiation 95 (CD95) (rs2234767), локуси, асоційовані з ВКЗАІТ, наявні на хромосомах 2 (2q33), 6 (6p21), 8 (8q24), 12 (12q22) і 13 (13q32), тощо [23-27].

Проте оцінка маркерів, які регулюють апоптоз (білок p53, Bcl-2, Fas-система) і проліферацію (білок Кі-67), а також їх зв'язок із поліморфізмом генів, що асоціюються з апоптозом, роль у цьому процесі автоімунних реакцій є недостатньо вивченими та вимагають подальших досліджень.

Мета дослідження - вивчення показників апоптозу та проліферації (експресія/щільність маркерів Fas/FasL, Bcl-2, p53 і Ki-67 на тиреоцитах у ділянках лімфоїдної інфільтрації та деструкції тиреоцитів, а також у морфологічно 
незмінених ділянках тканини Щ3 (контроль), підрахунок кількості імунореактивних клітин, які експресують ці маркери, AIT та АЩЗ із використанням імуногістохімічного методу та урахуванням поліморфізму генів $B C L-2$ (rs17759659), CTLA-4 (rs231775) i APO-1/Fas (rs2234767).

\section{Матеріал і методи}

Впродовж 2013-2016 рр. на базі Чернівецької обласної клінічної лікарні обстежено 125 жінок із хірургічною патологією Щ3, 95 із них були пацієнти з BЗАIT. Вік пацієнтів складав від 23 до 72 років. Діагноз було виставлено клінічно, лабораторно (антитіла до тиреопероксидази (АТПО) - 60-250 ОД/мл; антитіла до тиреоглобуліну (АТГ) - 60-500 ОД/мл; тиреотропний гормон (ТТГ) - 4-10 мОД/л) за допомогою імуноферментного аналізу, за допомогою УЗД Щ3 (форма, розміри, ехощільність, наявність об'ємних утворень) і підтверджено морфологічно після хірургічного лікування.

Серед усіх пацієнтів виділено групу з 30 жінок, у яких за даними УЗД, тонкоголкової аспіраційної пункційної біопсії (ТАПБ) і гістологічного дослідження після операції було діагностовано аденому ЩЗ. Виділили цю групу у зв’язку з тим, що ця патологія є однією з найбільш розповсюджених серед вузлових форм зоба. У цих пацієнтів проводили дослідження паренхіми неураженої вузлом, морфологічно незміненої контрлатеральної частки ЩЗ. Ці показники були контролем. Остаточне підтвердження морфологічно незміненої тканини отримували після гістологічного дослідження.

Усім хворим виконано оперативне втручання за загальноприйнятими показаннями. Обсяг операції - від гемітиреоїдектомії до тиреоїдектомії. У ході операції тканину ЩЗ забирали для імуногістохімічного дослідження не пізніше ніж 30 хв. після операції. У хворих на АЩЗ окремо брали для дослідження незмінену тканину протилежної частки ЩЗ та аденоматозну тканину. У хворих на BЗАIT забирали уражену вузлову тканину. Шматочки тканини масою 100-300 мг доправляли на льоду в лабораторію та відразу розрізали на 4-6 частин масою в середньому по 50-70 мг. Після поділу закривали в спеціальний пластиковий контейнер і зберігали за температури $-70{ }^{\circ} \mathrm{C}$ до виконання основних досліджень.
Заморожені фрагменти тканини переміщали 3 морозильника $\left(-70{ }^{\circ} \mathrm{C}\right)$ на предметне скло, де шляхом роздрібнення скальпелем на маленькі шматочки в фосфатно-сольовому буфері (ФСБ) отримували суспензію клітин. Отриману суспензію збирали в пластикову пробірку об'ємом 5-10 мл, додаючи 1-2 мл ФСБ, що містив 0,25\% розчин трипсину й ЕДТА 1 ммоль. Поміщали на 2 год. у термостат Cobas фірми «РОШ» (температура $37{ }^{\circ} \mathrm{C}$ ) у режимі постійного перемішування. Струшували на гомогенізаторі фірми «Vortex» і переливали рідину в конічну пробірку через нейлонові фільтри «Filcons» діаметром 35-50 мкм фірми «Partec» (Німеччина). Відмивали суспензію профільтрованих клітин 2 рази у ФСБ і за допомогою центрифугування ресуспендували осад, додаючи або видаляючи необхідну кількість ФСБ до кінцевої концентрації 1-2 на $10^{6}$ клітини в літрі. Кінцеву концентрацію визначали на апараті MICROS60-ot фірми «ABX DIAGNOSTICS» (Франція), який дозволяв розрахувати загальну кількість клітин за їх розмірами.

3 отриманої гетерогенної суспензії готували цитологічний препарат, який після забарвлення вивчався лікарями-морфологами для підтвердження виданих раніше гістологічних висновків про належність препарату досліджуваним нозологіями.

Для постановки імуногістохімічної реакції використовували моноклональні антитіла проти таких антигенів: Mouse Human Ki-67 FITC Clone MIB-1; Anti-p53 Protein Monoclonal Antibody, FITC Conjugated, Clone DO-7; Mouse Anti-Human Apoptosis Regulator Bcl-2 (BCL2) Monoclonal, Unconjugated, Clone 124 antibody; Mouse Anti-Human CD95 Monoclonal Antibody, Unconjugated, Clone FAS18; Mouse Anti-Human CD95L Monoclonal Antibody, Unconjugated, Clone NOK-1 фірми Dako Denmark A/S (Данія).

Щільність експресії мембранних (внутрішньоклітинних) рецепторів (білків) оцінювали в умовних одиницях (у.о.) за середньою інтенсивністю світіння флуоресценції (MFI), пропорційної номеру каналу, виміряного в логарифмічному режимі.

Для підрахунку клітин оцінювали показники проліферації та апоптозу в ділянках дослідження, використовуючи гейтування (рис. 1), коли визначали вікно, куди потрапляли клітини розміром до 25 мкм. 


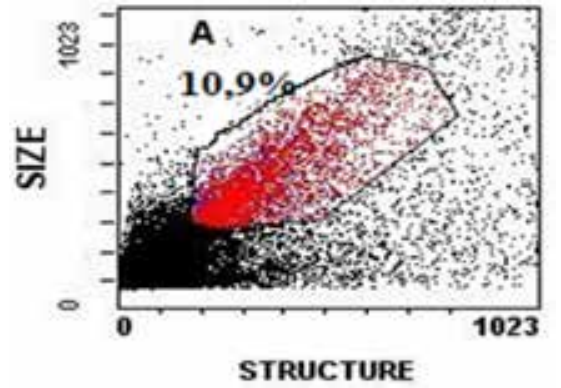

Pис. 1. Гістограма зони дослідження гетерогенної суспензії тканини Щз з обмеженою зоною гейтування (А).

Визначали кількість клітин та їх щільність із маркерами, розподіленими на поверхні клітин, - Fas, FasL і внутрішньоклітинних маркерів проліферації Кi-67 та апоптозу Bcl-2, p53. Фенотипування проводили на проточному цитофлуориметрі FACS Calibur фирмы BD Biosciences (США) з підрахунком 100000 випадків у зразку та розрахунком відносної кількості клітин, а також визначали показник щільності експресії рецепторів (білків) на клітинах або групі клітин. Цифрові дані (гістограми) у вигляді файлів (LMD) аналізували спеціальною аналітичною програмою CXР ver.2.2.

Генетичні дослідження виконували в лабораторії генетики на базі Державного університету медицини та фармації ім. М. Тестеміцану (Республіка Молдова). ДНК виділяли з лімфоцитів цільної венозної крові. Венозну кров зберігали в пробірках, стабілізованих К2-EDTA.

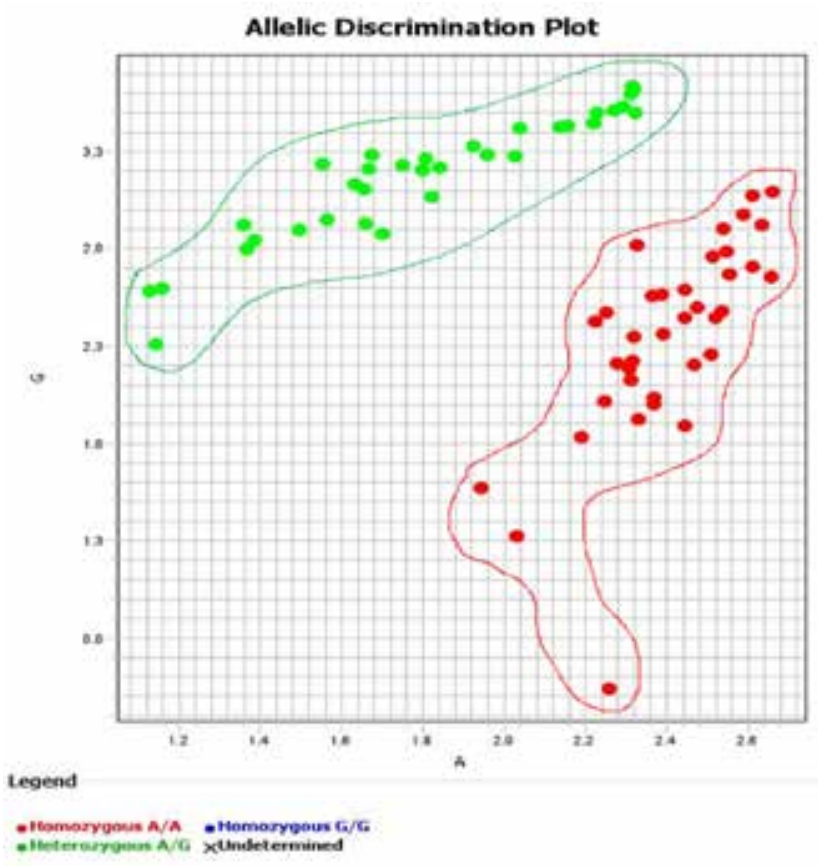

Рис. 2. Дискримінація алелей поліморфізму rs231775 гена CTLA4.
Виділення й очищення ДНК з отриманого матеріалу проводили відповідно до методичного керівництва Thermo Scientific GeneJET Genomic DNA Purification kit. \# K0721, Thermo Fisher Scientific. Для стандартизації умов проведення

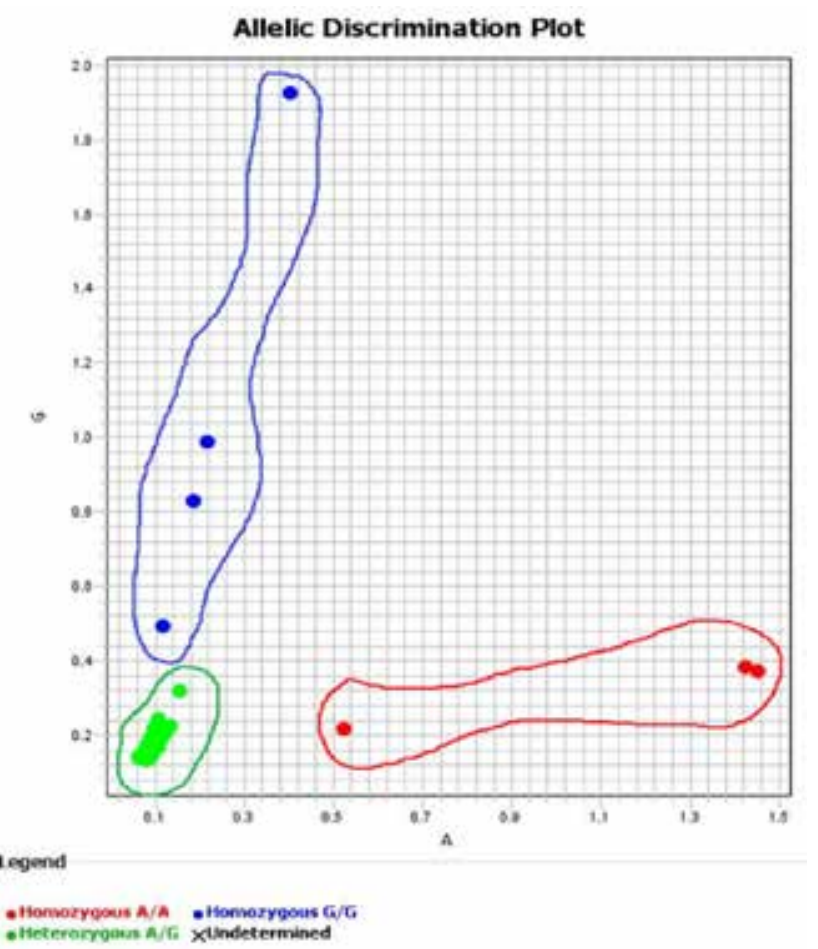

Pис. 3. Дискримінація алелей поліморфізму rs 17759659 гена BCL-2.

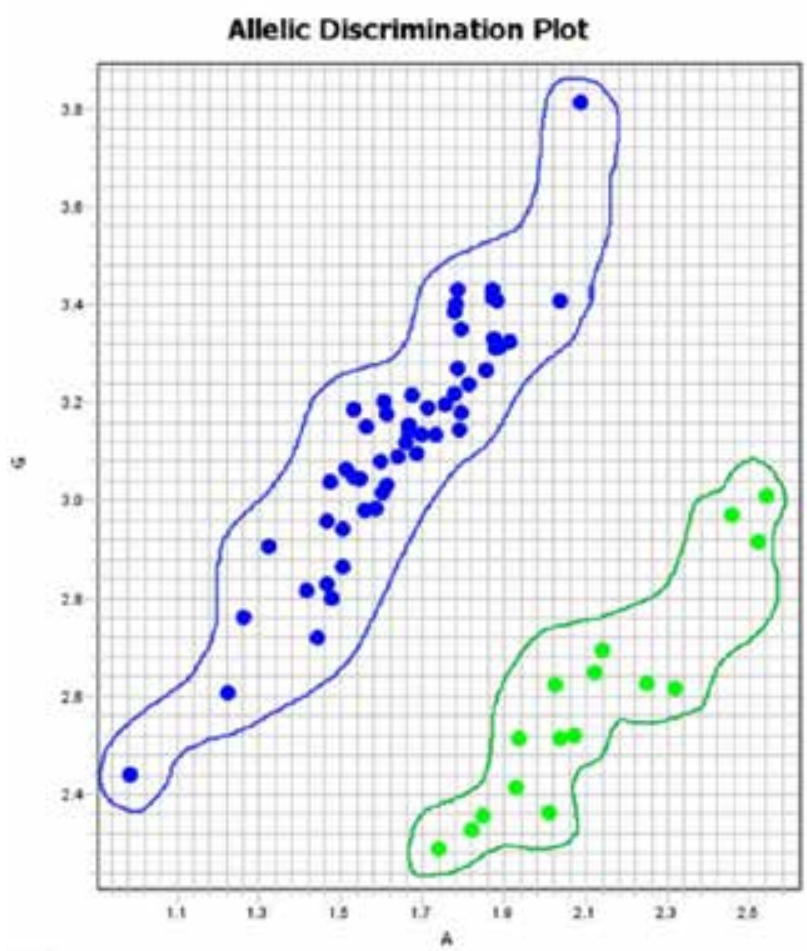

Pис. 4. Дискримінація алелей поліморфізму rs2234767 гена APO-1/Fas. 
визначення поліморфізмів усі проби було приведено до концентрації 2 нг/мкл розведенням ДНК у воді Nuclease-free water.

Полімеразну ланцюгову реакцію (ПЛР) проводили в режимі реального часу (RT-PCR) iз використанням Тaq-ДНК-полімерази та специфічних праймерів і зондів на обладнанні QuantStudio 6, Applied Biosystems (США), що дозволило отримати амплікони, визначити їх кількість у «реальному часі», а також зменшити ймовірність діагностичних помилок. Аналіз отриманих даних проводили із застосуванням програми QuantStudio RealTime Software.

Основну частину статистичного аналізу проведено 3 використанням програми «Statistica 7.0» (SPSS). Номінальні дані подано у вигляді абсолютних і відносних значень. Відповідність розподілу генотипів рівновазі Харді-Вайнберга перевіряли за допомогою Online Encyclopedia for Genetic Epidemiology Studies [28]. Для порівняння розподілу генотипів у дослідній і контрольній групах застосовували $\chi^{2}$-критерій Пірсона. Достовірність відмінностей середніх величин у групах із різними генотипами визначали за допомогою методики однофакторного дисперсійного аналізу (ANOVA). Вплив чинників на розвиток патології ЩЗ оцінювали за допомогою моделі бінарної логістичної регресії за величиною відносного ризику (RelR), відношенням ризиків (RR) і відношенням шансів (OR) $з$ 95\% довірчим інтервалом [95\% CI] з урахуванням критерію $\chi^{2}(\mathrm{df}=1)$. Різницю вважали достовірною за $\mathrm{p}<0,05$.

Дискримінацію генотипів проаналізованих проб поліморфізму rs231775 гена CTLA4, rs17759659 гена $B C L-2$ i rs2234767 гена $A P O-1 /$ Fas наведено на рисунках 2-4.

\section{Результати та обговорення}

Кількість клітин і щільність рецепторів із маркерами, розподіленими на поверхні клітин (Fas, FasL), і внутрішньоклітинних маркерів проліферації Кi-67 та апоптозу Bcl-2, p53 з урахуванням поліморфних варіантів гена $B C L-2$ (rs17759659) наведено в таблиці 1. Кількість імунореактивних клітин, які експресують на поверхні трансмембранний білок Fas, виявилася вірогідно більшою в гомозиготних носіїв мінорної G-алелі гена $B C L-2$, ніж у власників основної А-алелі (ААй AG-генотипи) на $18,54 \%\left(\mathrm{p}_{\mathrm{AA}}=0,043\right)$ і $36,18 \%$
$\left(\mathrm{p}_{\mathrm{AG}}=0,018\right)$ відповідно. За рештою показників (кількістю клітин із рецепторами до FasL i внутрішньоклітинних маркерів апоптозу - p53, Bcl-2 і проліферації - Кі-67 та щільністю цих маркерів як на поверхні, так і всередині клітини) 3 урахуванням поліморфізму гена $B C L-2$ (rs17759659) не встановлено. Відносно референтних значень контрольної групи загалом встановлено у хворих на патологію ЩЗ вірогідно вищі показники кількості клітин із рецепторами до Fas, FasL, Bcl-2 і Ki-67 (p $\leq 0,055-0,001$ ). Натомість щільність рецепторів Fas i FasL на поверхні тиреоцитів, навпаки, була вірогідно нижчою, ніж у контролі ( $<0,05)$, що не мало залежності від поліморфних варіантів гена $B C L-2$. Причому показники проліферації Кі-67 та апоптозу через білки-онкосупресори Bcl-2 і p53 у хворих на патологію Щ3 із щільністю відповідних білків всередині клітини вірогідно перевищували такі в групі контролю $(\mathrm{p}<0,05)$.

Однофакторний дисперсійний аналіз підтвердив асоціацію промотора гена $B C L-2$ (rs17759659) із кількістю клітин, що експресують Bcl-2 ( $\mathrm{F}=7,25 ; \mathrm{p}<0,001), \mathrm{p} 53 \quad(\mathrm{~F}=10,58$; $\mathrm{p}<0,001)$, Fas $(\mathrm{F}=25,33 ; \mathrm{p}<0,001)$, FasL $(\mathrm{F}=7,18$; $\mathrm{p}=0,001)$, Ki-67 ( $\mathrm{F}=3,60 ; \mathrm{p}=0,03)$, і щільністю рецепторів FasL ( $\mathrm{F}=9,74 ; \mathrm{p}<0,001)$ і маркера проліферації білка Кі-67 ( $\mathrm{F}=13,20 ; \mathrm{p}<0,001)$ (табл. 1).

Щільність рецепторів і кількість імунореактивних клітин-маркерів апоптозу та проліферації в тканині Щ3 з урахуванням поліморфних варіантів гена CTLA-4 (rs231775) наведено в таблиці 2. Щільність внутрішньоклітинного білка, що регулює процес проліферації, Кі-67 вірогідно переважала в носів мінорної алелі G (AG-, GG-генотипи) гена CTLA-4 порівняно 3 носіями АA-генотипу - на $10 \%(\mathrm{p}=0,033)$ i $11,5 \%(p=0,046)$ відповідно. За рештою маркерів вірогідних відмінностей залежно від поліморфізму гена $C T L A-4$ (rs231775) не встановлено. Кількість клітин із рецепторами до Fas, FasL і Ki-67, а також щільність внутрішньоклітинних антиапоптичних білків - p53 i Bcl-2 і проліферації - Кі-67 вірогідно переважали референтні значення контрольної групи ( $\mathrm{p} \leq 0,048-0,001)$.

Однофакторний дисперсійний аналіз підтвердив асоціацію промотора гена CTLA-4 (rs231775) із кількістю клітин, що експресують p53 $(\mathrm{F}=8,35 ; \mathrm{p}<0,001)$, Fas $(\mathrm{F}=4,23 ; \mathrm{p}=0,017)$, FasL $(\mathrm{F}=5,61: \mathrm{p}=0,005), \mathrm{Ki}-67(\mathrm{~F}=3,72 ; \mathrm{p}=0,027)$, і щільністю рецепторів Fas $(F=17,17 ; p=0,001)$, 
таблиця 1. Щільність рецепторів і кількість клітин із маркерами апоптозу та проліферації в тканині щитоподібної залози з урахуванням поліморфних варіантів гена BCL-2 (rs17759659)

\begin{tabular}{|c|c|c|c|c|}
\hline \multirow[t]{2}{*}{ Показник } & \multirow[b]{2}{*}{$\begin{array}{l}\text { Контроль } \\
\text { (морфо- } \\
\text { логічно } \\
\text { незмінена } \\
\text { тканина } \\
\text { щ3), n=25 }\end{array}$} & \multicolumn{3}{|c|}{ Генотипи гена BCL-2 у хворих } \\
\hline & & $\begin{array}{l}\text { AA, } \\
n=10\end{array}$ & $\begin{array}{l}\text { AG, } \\
n=110\end{array}$ & $\begin{array}{l}\mathrm{GG}, \\
\mathrm{n}=5\end{array}$ \\
\hline $\begin{array}{l}\text { Кількість } \\
\text { клітин Fas, \% }\end{array}$ & $0,79 \pm 0,04$ & $\begin{array}{l}23,28 \pm 2,30 \\
p<0,001\end{array}$ & $\begin{array}{l}18,24 \pm 3,89 \\
p<0,001\end{array}$ & $\begin{array}{l}28,58 \pm 0,55 \\
p<0,001 \\
P_{A A}=0,043 \\
P_{A G}=0,018\end{array}$ \\
\hline $\begin{array}{l}\text { Щільність } \\
\text { рецепторів } \\
\text { Fas, y.o. }\end{array}$ & $13,82 \pm 0,40$ & $\begin{array}{l}6,75 \pm 1,25 \\
p<0,001\end{array}$ & $\begin{array}{l}7,38 \pm 1,12 \\
p<0,001\end{array}$ & $\begin{array}{l}6,45 \pm 0,95 \\
p<0,001\end{array}$ \\
\hline $\begin{array}{l}\text { Кількість клі- } \\
\text { тин Fas L, \% }\end{array}$ & $3,85 \pm 0,16$ & $\begin{array}{l}11,93 \pm 1,71 \\
p=0,003\end{array}$ & $\begin{array}{l}10,57 \pm 1,34 \\
p=0,002\end{array}$ & $\begin{array}{l}12,14 \pm 1,45 \\
p=0,002\end{array}$ \\
\hline $\begin{array}{l}\text { Щільність } \\
\text { рецепторів } \\
\text { Fas L, y.o. }\end{array}$ & $11,13 \pm 0,85$ & $\begin{array}{l}7,57 \pm 0,96 \\
p=0,009\end{array}$ & $\begin{array}{l}8,29 \pm 0,64 \\
p=0,009\end{array}$ & $\begin{array}{l}7,34 \pm 0,39 \\
p=0,005\end{array}$ \\
\hline $\begin{array}{l}\text { Загальна кіль- } \\
\text { кість клітин } \\
\text { р53, \% }\end{array}$ & $64,14 \pm 1,89$ & $67,79 \pm 1,27$ & $59,47 \pm 7,0$ & $68,02 \pm 1,52$ \\
\hline $\begin{array}{l}\text { Щільність } \\
\text { білка р53, (за- } \\
\text { гальна), у.о. }\end{array}$ & $1,41 \pm 0,05$ & $\begin{array}{l}3,46 \pm 0,93 \\
p=0,035\end{array}$ & $\begin{array}{l}3,86 \pm 0,58 \\
p=0,004\end{array}$ & $\begin{array}{l}3,60 \pm 0,94 \\
p=0,028\end{array}$ \\
\hline $\begin{array}{l}\text { Кількість клі- } \\
\text { тин Кі-67, \% }\end{array}$ & $1,16 \pm 0,05$ & $\begin{array}{l}4,26 \pm 0,53 \\
p=0,001\end{array}$ & $\begin{array}{l}3,73 \pm 0,81 \\
p=0,001\end{array}$ & $\begin{array}{l}4,46 \pm 1,40 \\
p=0,026\end{array}$ \\
\hline $\begin{array}{l}\text { Щільність біл- } \\
\text { ка Кі-67, у.о. }\end{array}$ & $1,20 \pm 0,07$ & $\begin{array}{l}1,77 \pm 0,18 \\
p=0,006\end{array}$ & $\begin{array}{l}2,11 \pm 0,22 \\
p=0,005\end{array}$ & $\begin{array}{l}1,88 \pm 0,24 \\
p=0,012\end{array}$ \\
\hline $\begin{array}{l}\text { Кількість клі- } \\
\text { тин Вс1-2, \% }\end{array}$ & $73,05 \pm 1,35$ & $\begin{array}{l}80,66 \pm 2,99 \\
p=0,027\end{array}$ & $\begin{array}{l}78,22 \pm 2,44 \\
p=0,055\end{array}$ & $\begin{array}{l}81,23 \pm 3,47 \\
p=0,037\end{array}$ \\
\hline $\begin{array}{l}\text { Щільність біл- } \\
\text { ка Вс1-2, у.о. }\end{array}$ & $3,86 \pm 0,16$ & $\begin{array}{l}7,18 \pm 1,57 \\
p=0,043\end{array}$ & $\begin{array}{l}6,62 \pm 1,07 \\
p=0,013\end{array}$ & $\begin{array}{l}7,40 \pm 1,49 \\
p=0,026\end{array}$ \\
\hline
\end{tabular}

Примітка: $p$ - вірогідність різниці з показником групи контролю; $p_{A A}$ - вірогідність різниці з показником носіїв $A A$-генотипу; $p_{A G}-$ вірогідність різниці з показником носіїв AG-генотипу.

антиапоптичних $\mathrm{Bcl}-2$ ( $\mathrm{F}=3,09 ; \mathrm{p}=0,049)$ i p53 $(\mathrm{F}=18,18 ; \mathrm{p}<0,001)$ і маркера проліферації білка Ki-67 ( $\mathrm{F}=56,26 ; \mathrm{p}<0,001)$ (табл. 2).

Показники щільності рецепторів і кількість клітин-маркерів апоптозу та проліферації у тканині Щ3 не мали прямої залежності від поліморфних варіантів гена APO-1/Fas (rs2234767) (табл. 3). Кількість клітин із рецепторами до Fas, FasL i Ki-67, а також щільність внутрішньоклітинних антиапоптичних білків - p53 i Bcl-2 і проліферації - Кі-67 вірогідно перевищували референтні показники групи контролю $(\mathrm{p} \leq 0,019-0,001)$.

Однофакторний дисперсійний аналіз підтвердив асоціацію промотора гена $A P O-1 /$ Fas (rs2234767) із кількістю клітин, що експресують таблиця 2. Щільність рецепторів і кількість клітин із маркерами апоптозу та проліферації в тканині щитоподібної залози з урахуванням поліморфних варіантів гена CTLA-4 (rs231775)

\begin{tabular}{|c|c|c|c|c|}
\hline \multirow[t]{2}{*}{ Показники } & \multirow[b]{2}{*}{$\begin{array}{l}\text { Контроль } \\
\text { (морфо- } \\
\text { логічно } \\
\text { незмінена } \\
\text { тканина } \\
\text { щ3), n=25 }\end{array}$} & \multicolumn{3}{|c|}{ Генотипи гена CTLA-4 у хворих } \\
\hline & & $\begin{array}{l}\text { AA, } \\
n=59\end{array}$ & $\begin{array}{l}A G, \\
n=62\end{array}$ & $\begin{array}{l}\text { GG, } \\
n=4\end{array}$ \\
\hline $\begin{array}{l}\text { Кількість } \\
\text { клітин Fas, \% }\end{array}$ & $0,79 \pm 0,04$ & $\begin{array}{l}18,62 \pm 4,20 \\
p<0,001\end{array}$ & $\begin{array}{l}18,90 \pm 4,02 \\
p<0,001\end{array}$ & $\begin{array}{l}12,81 \pm 1,25 \\
p<0,001\end{array}$ \\
\hline $\begin{array}{l}\text { Щільність } \\
\text { рецепторів } \\
\text { Fas, y.o. }\end{array}$ & $13,82 \pm 0,40$ & $\begin{array}{l}7,48 \pm 1,32 \\
p=0,003\end{array}$ & $\begin{array}{l}7,10 \pm 1,80 \\
p=0,007\end{array}$ & $\begin{array}{l}10,12 \pm 1,05 \\
p=0,01\end{array}$ \\
\hline $\begin{array}{l}\text { Кількість } \\
\text { клітин Fas L, \% }\end{array}$ & $3,85 \pm 0,16$ & $\begin{array}{l}10,64 \pm 1,40 \\
p=0,003\end{array}$ & $\begin{array}{l}10,81 \pm 1,26 \\
p=0,002\end{array}$ & $\begin{array}{l}8,52 \pm 1,18 \\
p=0,006\end{array}$ \\
\hline $\begin{array}{l}\text { Щільність } \\
\text { рецепторів } \\
\text { Fas L, у.o. }\end{array}$ & $11,13 \pm 0,85$ & $\begin{array}{l}8,20 \pm 0,61 \\
p=0,009\end{array}$ & $\begin{array}{l}8,15 \pm 0,57 \\
p=0,004\end{array}$ & $\begin{array}{l}8,19 \pm 0,47 \\
p=0,005\end{array}$ \\
\hline $\begin{array}{l}\text { Загальна } \\
\text { кількість } \\
\text { клітин р53, \% }\end{array}$ & $64,14 \pm 1,89$ & $61,46 \pm 4,39$ & $58,39 \pm 5,26$ & $65,03 \pm 2,90$ \\
\hline $\begin{array}{l}\text { Щільність } \\
\text { білка р53, } \\
\text { (загальна), у.о. }\end{array}$ & $1,41 \pm 0,05$ & $\begin{array}{l}3,71 \pm 0,41 \\
p=0,002\end{array}$ & $\begin{array}{l}4,01 \pm 0,35 \\
p<0,001\end{array}$ & $\begin{array}{l}3,03 \pm 0,56 \\
p=0,008\end{array}$ \\
\hline $\begin{array}{l}\text { Кількість } \\
\text { клітин Кі-67, \% }\end{array}$ & $1,16 \pm 0,05$ & $\begin{array}{l}3,71 \pm 0,62 \\
p=0,005\end{array}$ & $\begin{array}{l}3,89 \pm 0,63 \\
p=0,004\end{array}$ & $\begin{array}{l}3,09 \pm 0,77 \\
p=0,019\end{array}$ \\
\hline $\begin{array}{l}\text { Щільність } \\
\text { білка Кі-67, у.о. }\end{array}$ & $1,20 \pm 0,07$ & $\begin{array}{l}2,0 \pm 0,08 \\
p<0,001\end{array}$ & $\begin{array}{l}2,20 \pm 0,11 \\
p<0,001 \\
p_{A A}=0,033\end{array}$ & $\begin{array}{l}2,23 \pm 0,08 \\
p<0,001 \\
p_{A A}=0,046\end{array}$ \\
\hline $\begin{array}{l}\text { Кількість } \\
\text { клітин Вс1-2, \% }\end{array}$ & $73,05 \pm 1,35$ & $78,49 \pm 3,24$ & $78,40 \pm 2,36$ & $77,21 \pm 4,82$ \\
\hline $\begin{array}{l}\text { Щільність } \\
\text { білка Вс1-2, у.о. }\end{array}$ & $3,86 \pm 0,16$ & $\begin{array}{l}6,61 \pm 0,60 \\
p=0,004\end{array}$ & $\begin{array}{l}6,79 \pm 0,64 \\
p=0,003\end{array}$ & $\begin{array}{l}6,08 \pm 1,0 \\
p=0,037\end{array}$ \\
\hline
\end{tabular}

Примітка: $p$ - вірогідність різниці з показником групи контролю;

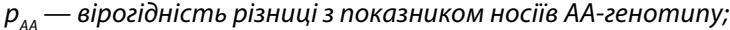
$p_{A G}$ - вірогідність різниці з показником носіїв $A G$-генотипу.

FasL ( $\mathrm{F}=8,37 ; \mathrm{p}=0,005)$ і щільністю рецепторів Fas $(\mathrm{F}=115,28 ; \mathrm{p}<0,001)$ і внутрішньоклітинного протеїну р53 ( $\mathrm{F}=10,62 ; \mathrm{p}=0,001)$ (табл. 3$)$.

За частотою збільшення (помірна, висока) або зменшення кількості клітин і щільності рецепторів, що експресують маркери апоптозу та проліферації, з урахуванням поліморфізму гена APO-1/Fas (rs2234767) встановили тенденції, аналогічні описаним у таблиці 3 із різницею у частоті 3,08 і 3,60 раза ( $<<0,001)$, без вірогідних відмінностей за поліморфними варіантами гена Fas (rs2234767).

Аналіз маркерів апоптозу та проліферації як чинників ризику досліджуваної патології Щ3 засвідчив, що високе компенсаторне підвищення вмісту клітин у тканині, що експре- 
Оригінальні дослідження

таблиця 3. Щільність рецепторів і кількість клітин із маркерами апоптозу та проліферації в тканині щитоподібної залози з урахуванням поліморфних варіантів гена APO-1/Fas (rs2234767)

\begin{tabular}{|c|c|c|c|}
\hline \multirow[t]{2}{*}{ Показник } & \multirow{2}{*}{$\begin{array}{l}\text { Контроль } \\
\text { (морфологічно } \\
\text { незмінена тканина } \\
\text { Щ3), n=25 }\end{array}$} & \multicolumn{2}{|c|}{$\begin{array}{l}\text { Генотипи гена APO-1/ } \\
\text { Fas у хворих }\end{array}$} \\
\hline & & $\begin{array}{l}\mathrm{AG}, \\
\mathrm{n}=23\end{array}$ & $\begin{array}{l}\text { GG, } \\
n=102\end{array}$ \\
\hline $\begin{array}{l}\text { Кількість } \\
\text { клітин Fas, \% }\end{array}$ & $0,79 \pm 0,04$ & $\begin{array}{l}17,70 \pm 4,35 \\
p<0,001\end{array}$ & $\begin{array}{l}18,75 \pm 4,25 \\
p<0,001\end{array}$ \\
\hline $\begin{array}{l}\text { Щільність } \\
\text { рецепторів } \\
\text { Fas, у.о. }\end{array}$ & $13,82 \pm 0,40$ & $\begin{array}{l}7,10 \pm 1,80 \\
p=0,007\end{array}$ & $\begin{array}{l}10,12 \pm 1,05 \\
p=0,009\end{array}$ \\
\hline $\begin{array}{l}\text { Кількість } \\
\text { клітин } \\
\text { Fas L, \% }\end{array}$ & $3,85 \pm 0,16$ & $\begin{array}{l}7,95 \pm 1,17 \\
p=0,008\end{array}$ & $\begin{array}{l}7,25 \pm 1,02 \\
p=0,009\end{array}$ \\
\hline $\begin{array}{l}\text { Щільність } \\
\text { рецепторів } \\
\text { Fas L, у.о. }\end{array}$ & $11,13 \pm 0,85$ & $10,30 \pm 1,42$ & $10,73 \pm 1,33$ \\
\hline $\begin{array}{l}\text { Загальна } \\
\text { кількість } \\
\text { клітин р53, \% }\end{array}$ & $64,14 \pm 1,89$ & $60,83 \pm 4,59$ & $60,09 \pm 4,83$ \\
\hline $\begin{array}{l}\text { Щільність } \\
\text { білка р53, } \\
\text { (загальна), } \\
\text { у.о. }\end{array}$ & $1,41 \pm 0,05$ & $\begin{array}{l}3,58 \pm 0,41 \\
p=0,002\end{array}$ & $\begin{array}{l}3,87 \pm 0,38 \\
p=0,001\end{array}$ \\
\hline $\begin{array}{l}\text { Кількість } \\
\text { клітин } \\
\text { Кі-67, \% }\end{array}$ & $1,16 \pm 0,05$ & $\begin{array}{l}3,72 \pm 0,66 \\
p=0,006\end{array}$ & $\begin{array}{l}3,79 \pm 0,63 \\
p=0,004\end{array}$ \\
\hline $\begin{array}{l}\text { Щільність } \\
\text { білка Кі-67, } \\
\text { у.о. }\end{array}$ & $1,20 \pm 0,07$ & $\begin{array}{l}2,02 \pm 0,20 \\
p=0,006\end{array}$ & $\begin{array}{l}2,09 \pm 0,21 \\
p=0,005\end{array}$ \\
\hline $\begin{array}{l}\text { Кількість } \\
\text { клітин } \\
\text { Вс1-2, \% }\end{array}$ & $73,05 \pm 1,35$ & $78,34 \pm 2,63$ & $\begin{array}{l}78,42 \pm 1,81 \\
p=0,02\end{array}$ \\
\hline $\begin{array}{l}\text { Щільність } \\
\text { білка Вс1-2, } \\
\text { у.о. }\end{array}$ & $3,86 \pm 0,16$ & $\begin{array}{l}6,49 \pm 0,63 \\
p=0,005\end{array}$ & $\begin{array}{l}6,70 \pm 0,58 \\
p=0,003\end{array}$ \\
\hline
\end{tabular}

Примітка: $p$ - вірогідність різниці з показником групи контролю.

сують Fas, FasL i Ki-67, і помірне збільшення кількості клітин із Bcl-2 на тлі сильного зменшення щільності рецепторів на поверхні клітин iз Fas i FasL i підвищення щільності всередині клітини антиапоптичного протеїну Bcl-2 підвищує ризик патології ЩЗ (АIT та АЩЗ) у 2,79 і 9 разів у носіїв AG- i, надто, AA-генотипів гена BCL-2 (rs17759659) $(\mathrm{OR}=7,80$ і $\mathrm{OR}=81,0$ відповідно; $\mathrm{p}<0,001 ;$ табл. 4). Натомість високе підвищення щільності білка проліферації Ki-67 на тлі зменшення кількості клітин, що містять протеїн онкосупресії р53 сильного (>50 перцентиль) і помірного ( $\leq 50$ перцентиль) зниження таких із Bcl-2 білком є чинником протекції та роблять шанси на появу AIT та АЩЗ най- таблиця 4. Поліморфні варіанти гена BCL-2 (rs17759659) як чинники ризику апоптозу та проліферації в тканині щитоподібної залози

\begin{tabular}{|c|c|c|c|c|c|c|}
\hline \multicolumn{2}{|l|}{ Показник } & \multirow{2}{*}{$\begin{array}{l}\text { RelR } \\
9,0\end{array}$} & \multirow{2}{*}{$\begin{array}{l}\text { OR } \\
81,0\end{array}$} & \multirow{2}{*}{$\begin{array}{l}\mathbf{9 5 \%} \\
\text { CI RR } \\
1,38- \\
58,44\end{array}$} & \multirow{2}{*}{$\begin{array}{l}\mathbf{9 5 \%} \\
\text { CI OR } \\
4,36- \\
1504,5\end{array}$} & \multirow{2}{*}{$\begin{array}{l}\mathbf{P} \\
<0,001\end{array}$} \\
\hline $\begin{array}{l}\text { Кількість } \\
\text { клітин Fas, FasL }\end{array}$ & $\mathrm{AA}$ & & & & & \\
\hline $\begin{array}{l}\text { і Кі-67, \% (високе } \\
\text { підвищення) }\end{array}$ & $A G$ & 2,79 & 7,80 & $\begin{array}{l}2,0- \\
3,89\end{array}$ & $\begin{array}{l}4,28- \\
14,21\end{array}$ & $<0,001$ \\
\hline $\begin{array}{l}\text { Щільність } \\
\text { рецепторів Fas }\end{array}$ & AA & 9,0 & 81,0 & $\begin{array}{l}1,38- \\
58,44\end{array}$ & $\begin{array}{l}4,36- \\
1504,5\end{array}$ & $<0,001$ \\
\hline $\begin{array}{l}\text { i FasL, у.о. (сильне } \\
\text { зменшення) }\end{array}$ & $A G$ & 2,79 & 7,80 & $\begin{array}{l}2,0- \\
3,89\end{array}$ & $\begin{array}{l}4,28- \\
14,21\end{array}$ & $<0,001$ \\
\hline $\begin{array}{l}\text { Щільність білка } \\
\text { Кі-67, у.о. (високе }\end{array}$ & $\mathrm{AA}$ & 0,11 & 0,01 & $\begin{array}{l}0,02- \\
0,72\end{array}$ & $\begin{array}{l}0,001- \\
0,23\end{array}$ & $<0,001$ \\
\hline підвищення) & $A G$ & 0,36 & 0,13 & $\begin{array}{l}0,26- \\
0,50\end{array}$ & $\begin{array}{l}0,07- \\
0,23\end{array}$ & $<0,001$ \\
\hline $\begin{array}{l}\text { Загальна } \\
\text { кількість клітин }\end{array}$ & AA & 0,11 & 0,01 & $\begin{array}{l}0,02- \\
0,72\end{array}$ & $\begin{array}{l}0,001- \\
0,23\end{array}$ & $<0,001$ \\
\hline $\begin{array}{l}\text { p53, \% (сильне } \\
\text { зменшення) }\end{array}$ & $A G$ & 0,36 & 0,13 & $\begin{array}{l}0,26- \\
0,50\end{array}$ & $\begin{array}{l}0,07- \\
0,23\end{array}$ & $<0,001$ \\
\hline $\begin{array}{l}\text { Кількість клітин } \\
\text { Вс1-2, \% (помірне }\end{array}$ & $\mathrm{AA}$ & 0,11 & 0,01 & $\begin{array}{l}0,02- \\
0,72\end{array}$ & $\begin{array}{l}0,001- \\
0,23\end{array}$ & $<0,001$ \\
\hline зменшення) & $A G$ & 0,36 & 0,13 & $\begin{array}{l}0,26- \\
0,50\end{array}$ & $\begin{array}{l}0,07- \\
0,23\end{array}$ & $<0,001$ \\
\hline $\begin{array}{l}\text { Кількість клітин } \\
\text { Вс1-2, \% (помірне }\end{array}$ & $\mathrm{AA}$ & 9,0 & 81,0 & $\begin{array}{l}1,38- \\
58,44\end{array}$ & $\begin{array}{l}4,36- \\
1504,5\end{array}$ & $<0,001$ \\
\hline збільшення) & $A G$ & 2,79 & 7,80 & $\begin{array}{l}2,0- \\
3,89\end{array}$ & $\begin{array}{l}4,28- \\
14,21\end{array}$ & $<0,001$ \\
\hline $\begin{array}{l}\text { Щільність білка } \\
\text { Вс1-2, у.о. (високе }\end{array}$ & AA & 9,0 & 81,0 & $\begin{array}{l}1,38- \\
58,44\end{array}$ & $\begin{array}{l}4,36- \\
1504,5\end{array}$ & $<0,001$ \\
\hline підвищення) & $A G$ & 2,79 & 7,80 & $\begin{array}{l}2,0- \\
3,89\end{array}$ & $\begin{array}{l}4,28- \\
14,21\end{array}$ & $<0,001$ \\
\hline
\end{tabular}

Примітка: RelR (relative risk) — відносний ризик; OR (Odds Ratio) відношення шансів; 95\% CI RR, OR (confidence interval) — довірчий інтервал відношення ризиків (RR), шансів (OR).

нижчими в обстеженій популяції мешканців Північної Буковини незалежно від генотипів гена $B C L-2(\mathrm{OR}=0,01 ; 95 \%$ CI OR: 0,001-0,23 для AA-генотипу й OR=0,13; 95\% CI OR: 0,07-0,23 для AG-генотипу; $\mathrm{p}<0,001)$.

Методами клінічної епідеміології встановлено, що аналізовані маркери апоптозу та проліферації в тканині ЩЗ (високий вміст клітин y тканині, що експресують Fas, FasL, Ki-67, Bcl-2, сильне зменшення щільності рецепторів на поверхні клітин із Fas i FasL i високе зростання щільності протеїну Bcl-2) підвищують ризик патології Щ3 (АІT та АЩЗ) у 3,92 раза в носіїв AA-генотипу гена $C T L A-4(\mathrm{OR}=15,34 ; 95 \% \mathrm{CI}$ OR: $6,26-37,60 ; \mathrm{p}<0,001)$ і в 2,44 раза в осіб із AGгенотипом гена $C T L A-4(\mathrm{OR}=5,98 ; 95 \% \mathrm{CI} O \mathrm{OR}$ : $2,75-12,98 ;$ p $<0,001 ;$ табл. 5) і в 3,08 раза в гомозиготних носіїв основної G-алелі гена $A P O-1 / F a s$ 
Таблиця 5. Поліморфні варіанти гена CTLA-4 (rs231775) як чинники ризику апоптозу та проліферації в тканині щитоподібної залози

\begin{tabular}{|c|c|c|c|c|c|c|}
\hline Показник & & RelR & OR & $\begin{array}{l}95 \% \\
\text { CI RR }\end{array}$ & $\begin{array}{l}95 \% \\
\text { CI OR }\end{array}$ & $p$ \\
\hline \multirow{2}{*}{$\begin{array}{l}\text { Кількість } \\
\text { клітин Fas, FasL } \\
\text { і Кі-67, \% (високе } \\
\text { підвищення) }\end{array}$} & $\mathrm{AA}$ & 3,92 & 15,34 & $\begin{array}{l}2,33- \\
6,60\end{array}$ & $\begin{array}{l}6,26- \\
37,60\end{array}$ & $<0,001$ \\
\hline & $A G$ & 2,44 & 5,98 & $\begin{array}{l}1,61- \\
3,72\end{array}$ & $\begin{array}{l}2,75- \\
12,98\end{array}$ & $<0,001$ \\
\hline \multirow{2}{*}{$\begin{array}{l}\text { Щільність } \\
\text { рецепторів Fas } \\
\text { i FasL, у.о. (сильне } \\
\text { зменшення) }\end{array}$} & $A A$ & 3,92 & 15,34 & $\begin{array}{l}2,33- \\
6,60\end{array}$ & $\begin{array}{l}6,26- \\
37,60\end{array}$ & $<0,001$ \\
\hline & $A G$ & 2,44 & 5,98 & $\begin{array}{l}1,61- \\
3,72\end{array}$ & $\begin{array}{l}2,75- \\
12,98\end{array}$ & $<0,001$ \\
\hline \multirow{2}{*}{$\begin{array}{l}\text { Щільність білка } \\
\text { Кі-67, у.о. (високе } \\
\text { підвищення) }\end{array}$} & $A A$ & 0,25 & 0,07 & $\begin{array}{l}0,15- \\
0,43\end{array}$ & $\begin{array}{l}0,03- \\
0,16\end{array}$ & $<0,001$ \\
\hline & $A G$ & 0,41 & 0,17 & $\begin{array}{l}0,27- \\
0,62\end{array}$ & $\begin{array}{l}0,08- \\
0,36\end{array}$ & $<0,001$ \\
\hline \multirow{2}{*}{$\begin{array}{l}\text { Загальна } \\
\text { кількість клітин } \\
\text { р53, \% (сильне } \\
\text { зменшення) }\end{array}$} & $A A$ & 0,25 & 0,07 & $\begin{array}{l}0,15- \\
0,43\end{array}$ & $\begin{array}{l}0,03- \\
0,16\end{array}$ & $<0,001$ \\
\hline & $A G$ & 0,41 & 0,17 & $\begin{array}{l}0,27- \\
0,62\end{array}$ & $\begin{array}{l}0,08- \\
0,36\end{array}$ & $<0,001$ \\
\hline \multirow{2}{*}{$\begin{array}{l}\text { Кількість клітин } \\
\text { Вс1-2, \% (помірне } \\
\text { зменшення) }\end{array}$} & $A A$ & 0,25 & 0,07 & $\begin{array}{l}0,15- \\
0,43\end{array}$ & $\begin{array}{l}0,03- \\
0,16\end{array}$ & $<0,001$ \\
\hline & $A G$ & 0,41 & 0,17 & $\begin{array}{l}0,27- \\
0,62\end{array}$ & $\begin{array}{l}0,08- \\
0,36\end{array}$ & $<0,001$ \\
\hline \multirow{2}{*}{$\begin{array}{l}\text { Кількість клітин } \\
\text { Вс1-2, \% (помірне } \\
\text { збільшення) }\end{array}$} & $A A$ & 3,92 & 15,34 & $\begin{array}{l}2,33- \\
6,60\end{array}$ & $\begin{array}{l}6,26- \\
37,60\end{array}$ & $<0,001$ \\
\hline & $A G$ & 2,44 & 5,98 & $\begin{array}{l}1,61- \\
3,72\end{array}$ & $\begin{array}{l}2,75- \\
12,98\end{array}$ & $<0,001$ \\
\hline \multirow{2}{*}{$\begin{array}{l}\text { Щільність білка } \\
\text { Вс1-2, у.о. (високе } \\
\text { підвищення) }\end{array}$} & $A A$ & 3,92 & 15,34 & $\begin{array}{l}2,33- \\
6,60\end{array}$ & $\begin{array}{l}6,26- \\
37,60\end{array}$ & $<0,001$ \\
\hline & $A G$ & 2,44 & 5,98 & $\begin{array}{l}1,61- \\
3,72\end{array}$ & $\begin{array}{l}2,75- \\
12,98\end{array}$ & $<0,001$ \\
\hline
\end{tabular}

Примітка: RelR (relative risk) - відносний ризик; OR (Odds Ratio) відношення шансів; 95\% CI RR, OR (confidence interval) — довірчий інтервал відношення ризиків (RR), шансів (OR).

(rs2234767) (табл. 6) і в 3,60 раза - у гетерозиготних носіїв AG-генотипу цього гена $(\mathrm{OR}=9,49$; 95\% CI OR: 5,01-17,96 i OR=12,96; 95\% CI OR: 3,19-52,62 відповідно, $\mathrm{p}<0,001)$.

Чинниками, які зменшують ймовірність появи AIT та АЩЗ в обстежених незалежно від генотипів генів CTLA-4 (rs231775) та APO-1/Fas (rs2234767) виявилися (табл. 5, 6): високе компенсаторне підвищення щільності білка проліферації Кi-67 і редукція вмісту клітин, що містять протеїни р53 або Bcl-2 (OR=0,07-0,17; 95\% CI OR: 0,03-0,36; $<<0,001$ i OR=0,08-0,11; 95\% CI OR: 0,02-0,31; відповідно, $\mathrm{p}<0,001)$.

Отже, у хворих на AIT та АЩЗ активуються декілька ланок програмованого кілінгу тиреоцитів із перевагою Fas-індукованого апоптозу, який найсильніше асоціюється 3 промотором гена $B C L-2 \quad(\operatorname{rs} 17759659) \quad(\mathrm{F}=25,33 ; \mathrm{p}<0,001)$
Таблиця 6. Поліморфні варіанти гена APO-1/Fas (rs2234767) як чинники ризику апоптозу та проліферації в тканині щитоподібної залози

\begin{tabular}{|c|c|c|c|c|c|c|}
\hline Показник & & RelR & OR & $\begin{array}{l}95 \% \mathrm{Cl} \\
\mathbf{R R}\end{array}$ & $\begin{array}{l}95 \% \mathrm{Cl} \\
\text { OR }\end{array}$ & $p$ \\
\hline \multirow{2}{*}{$\begin{array}{l}\text { Кількість } \\
\text { клітин Fas, FasL } \\
\text { і Кі-67, \% (високе } \\
\text { підвищення) }\end{array}$} & $A G$ & 3,60 & 12,96 & $\begin{array}{l}1,61- \\
8,05\end{array}$ & $\begin{array}{l}3,19- \\
52,62\end{array}$ & $<0,001$ \\
\hline & $\mathrm{GG}$ & 3,08 & 9,49 & $\begin{array}{l}2,15- \\
4,41\end{array}$ & $\begin{array}{l}5,01- \\
17,96\end{array}$ & $<0,001$ \\
\hline \multirow{2}{*}{$\begin{array}{l}\text { Щільність } \\
\text { рецепторів } \\
\text { Fas i FasL, } \\
\text { у.о. (сильне } \\
\text { зменшення) }\end{array}$} & $A G$ & 3,60 & 12,96 & $\begin{array}{l}1,61- \\
8,05\end{array}$ & $\begin{array}{l}3,19- \\
52,62\end{array}$ & $<0,001$ \\
\hline & GG & 3,08 & 9,49 & $\begin{array}{l}2,15- \\
4,41\end{array}$ & $\begin{array}{l}5,01- \\
17,96\end{array}$ & $<0,001$ \\
\hline \multirow{2}{*}{$\begin{array}{l}\text { Щільність білка } \\
\text { Кі-67, у.о. (високе } \\
\text { підвищення) }\end{array}$} & $A G$ & 0,28 & 0,08 & $\begin{array}{l}0,12- \\
0,62\end{array}$ & $\begin{array}{l}0,02- \\
0,31\end{array}$ & $<0,001$ \\
\hline & GG & 0,32 & 0,11 & $\begin{array}{l}0,23- \\
0,46\end{array}$ & $\begin{array}{l}0,06- \\
0,20\end{array}$ & $<0,001$ \\
\hline \multirow{2}{*}{$\begin{array}{l}\text { Загальна } \\
\text { кількість клітин } \\
\text { р53, \% (сильне } \\
\text { зменшення) }\end{array}$} & $A G$ & 0,28 & 0,08 & $\begin{array}{l}0,12- \\
0,62\end{array}$ & $\begin{array}{l}0,02- \\
0,31\end{array}$ & $<0,001$ \\
\hline & GG & 0,32 & 0,11 & $\begin{array}{l}0,23- \\
0,46\end{array}$ & $\begin{array}{l}0,06- \\
0,20\end{array}$ & $<0,001$ \\
\hline \multirow{2}{*}{$\begin{array}{l}\text { Кількість } \\
\text { клітин Вс1- } \\
\text { 2, \% (помірне } \\
\text { зменшення) }\end{array}$} & $A G$ & 0,28 & 0,08 & $\begin{array}{l}0,12- \\
0,62\end{array}$ & $\begin{array}{l}0,02- \\
0,31\end{array}$ & $<0,001$ \\
\hline & GG & 0,32 & 0,11 & $\begin{array}{l}0,23- \\
0,46\end{array}$ & $\begin{array}{l}0,06- \\
0,20\end{array}$ & $<0,001$ \\
\hline \multirow{2}{*}{$\begin{array}{l}\text { Кількість } \\
\text { клітин Вс1- } \\
\text { 2,\% (помірне } \\
\text { збільшення) }\end{array}$} & $A G$ & 3,60 & 12,96 & $\begin{array}{l}1,61- \\
8,05\end{array}$ & $\begin{array}{l}3,19- \\
52,62\end{array}$ & $<0,001$ \\
\hline & GG & 3,08 & 9,49 & $\begin{array}{l}2,15- \\
4,41\end{array}$ & $\begin{array}{l}5,01- \\
17,96\end{array}$ & $<0,001$ \\
\hline \multirow{2}{*}{$\begin{array}{l}\text { Щільність } \\
\text { білка Вс1-2, } \\
\text { у.о. (високе } \\
\text { підвищення) }\end{array}$} & $A G$ & 3,60 & 12,96 & $\begin{array}{l}1,61- \\
8,05\end{array}$ & $\begin{array}{l}3,19- \\
52,62\end{array}$ & $<0,001$ \\
\hline & $\mathrm{GG}$ & 3,08 & 9,49 & $\begin{array}{l}2,15- \\
4,41\end{array}$ & $\begin{array}{l}5,01- \\
17,96\end{array}$ & $<0,001$ \\
\hline
\end{tabular}

Примітка: RelR (relative risk) - відносний ризик; OR (Odds Ratio) відношення шансів; 95\% CI RR, OR (confidence interval) — довірчий інтервал відношення ризиків (RR), шансів (OR).

і майже у 6 разів слабше - 3 промотором гена CTLA-4 (rs231775) $(\mathrm{F}=4,23, \mathrm{p}=0,017)$ через виражену експресію Fas i FasL на поверхні клітин у ділянках лімфоїдної інфільтрації та деструкції тиреоцитів (сильніше в носіїв GG-генотипу гена $B C L-2$ - на $18,54 \%\left(\mathrm{p}_{\mathrm{AA}}=0,043\right)$ і $36,18 \%$ $\left(\mathrm{p}_{\mathrm{AG}}=0,018\right)$ відповідно $)$, що свідчить про ініціацію зовнішнього шляху апоптозу через каспазний механізм (ефекторну каспазу 8).

\section{Висновки}

1. Підвищена експресія Bcl-2 у лімфоцитах Щ3 хворих на AIT та АЩЗ асоціюється виключно з промоторним регіоном гена $B C L-2$ (rs17759659) без чіткої залежності за окремими поліморфними варіантами, із невірогід- 
ними змінами експресії білка р53 (теж асоціюється з поліморфним сайтом $B C L-2)$, що свідчить про незначне стримування процесів апоптозу (попри компенсаторне зростання щільності р53 всередині тиреоциту, що, хоча й пов'язано з промоторними регіонами генів CTLA-4 та APO-1/Fas, проте не впливає вагомо на експресію даного білка) з можливим подовженням часу виживання клітини та недостатнім видаленням 3 пулу тих клітин, які $є$ потенційно онкогенними, що гіпотетично може провокувати канцерогенез.

2. У хворих на AIT та АЩЗ компенсаторно збільшується кількість імунореактивних клітин, які експресують Кі-67, і щільність даного протеїну, що найсильніше асоціюється з поліморфним сайтом гена $C T L A-4$ і майже в 4 рази слабше - 3 промотором гена $B C L-2$ і є вірогідно вищою лише у власників мінорної G-алелі гена $C T L A-4$ на 10\% і 11,5\% відповідно, що свідчить про підтримання регенерації збереженого фолікулярного епітелію ЩЗ, надто в носіїв даної алелі.

3. Високий вміст у тканині ЩЗ клітин, що експресують Fas, FasL, Ki-67, Bcl-2 на тлі зменшення щільності рецепторів Fas i FasL на поверхні клітин і високого зростання щільності протеїну Bcl-2 підвищують ризик патології ЩЗ (АIT та АЩЗ): у 2,79 і 9 разів у ноciїв AG- i, надто, AА-генотипів гена $B C L-2$ (rs17759659), у 2,44 і 3,92 раза в носіїв AGi АА-генотипів гена $C T L A-4$, у 3,08 і 3,60 раза в гомозиготних носіїв основної G-алелі та AG-генотипу гена APO-1/Fas (rs2234767).

4. Чинниками протекції, які зменшують ймовірність появи AIT та АЩЗ, в обстеженій популяції мешканців Північної Буковини незалежно від генотипів аналізованих генів є: компенсаторне підвищення щільності білка проліферації всередині тиреоциту Ki-67 і редукція вмісту клітин, що містять протеїни р53 або Bcl-2.

\section{Список використаної літератури}

1. Калоева АА, Боташева ВС, Эркенова ЛД. Характер морфологических изменений при эндемическом зобе. Фундаментальные исследования. 2015; 1 (1):30-40. (Kaloyeva AA, Botasheva VS, Erkenova LD. Character of morphological changes during endemic goiter. Fundamental'nyye issledovaniya. 2015;1(1): 30-40.

2. Brix TH, Hegedus L. Twin studies as a model for exploring the aetiology of autoimmune thyroid disease. Clin Endocrinol (Oxf). 2012;76(4):457-64.

3. Бондаренко ОО, Шпонька ИС, Гриценко ПА. Использование онкомаркеров в морфологической диагностике эпителиальных опухолей щитовидной железы. Морфологія. 2010; 3(2):12-6. (Bondarenko OO, Shponika IS, Gritsenko PA. The use of tumor markers in the diagnosis of morphological epithelial tumors of thyroid gland. Morfologiya. 2010;3(2):12-6).

4. Tomer Y. Genetic susceptibility to autoimmune thyroid disease: past, present, andfuture. Thyroid. 2010;20(7):715-25.

5. Dong YH, Fu DG. Autoimmune thyroid disease: mechanism, genetics and current knowledge. Eur Rev Med Pharmacol Sci. 2014;18(23): 3611-8.

6. Tsyganenko OS, Voroschuk RS. Immunomorfological reaction in the thyroid tissue in patients with autoimmune thyroiditis in combination with nodular goiter. Arta Medica. Nicholae Anestiadi, Tenth Congress of the Association of Surgeons of Moldova, Chisinau. 2007;4(25):51-2.

7. Sheremet MI, Sydorchuk LP, Shidlovskyi VO, Bedenyuk AD Research of prognostic markers of proliferation and apoptosis in patients with nodular goiters combined with autoimmune thyroiditis. Archives of the Balkan Medical Union. 2016;51(4):488-91.

8. Sheremet MI, Sydorchuk LP, Shidlovskyi VO, Bedenyuk AD. New prognostic markers of nodular forms of goiter combined with autoimmune thyroiditis. J Education, Health \& Sport. 2017;7(3):475-82.

9. Sheremet MI, Shidlovskyi VO, Sydorchuk LP. Assessment of proliferation and apoptosis markers in patients with autoimmune thyroiditis. J Education, Health \& Sport. 2016;6(1):179-88.

10. Хазієв IB, Сорокіна ВВ. Експресія онкомаркерів Кі-67 і р53 у фолікулярних неоплазіях щитоподібної залози. Експериментальна і клінічна медицина. 2013;59(2):77-81. (Khaziyev IV, Sorokina VV Expression of tumor markers Ki-67 and p53 in follicular thyroid neoplasia. Eksperymental'na i klinichna medytsyna. 2013;59(2):77-81).

11. Choudhury M. Diagnostic utility of Ki-67 and p53 immunostaining on solitary thyroid nodule - a cytohistological and radionuclide scintigraphic study. Indian J Pathol Microbiol. 2011; 54(3):472-5.

12. Andrikoula M, Kolaitis N, Vartholomatos G. Serum levels of soluble Fas in patients with multinodular goiter. Immunol Investig. 2009;38(5): 398-407.

13. Basolo F. Suppression of Fas expression and down-regulation of Fas ligand in highly aggressive human thyroid carcinoma. Lab Invest. 2000;80(9):1413-9.

14. Chistiakov DA. Immunogenetics of Hashimoto's thyroiditis. J Autoimmun Dis. 2005;2:1-21

15. Kazakov SP, Kushlinsky NYe. The investigation of CD95, p53, bcl-2 and Ki-67 markers in autoimmune thyroid pathology patients. First Joint Meeting of European National Societies of Immunology Under the auspicesof EFIS and 16th European Congress of Immunology: ECI. 2006 Sept 6-9; Paris, France: 547.

16. Eschler DC, Hasham A, Tomer Y. Cutting edge: the etiology of autoimmune thyroid diseases. Clin Rev Allergy Immunol. 2011;13:33-9.

17. Nikiforova MN, Tseng GC, Steward D, Diorio D, Nikiforov YE MicroRNA expression profiling of thyroid tumors: biological significance and diagnostic utility. J Clin Endocrinol Metab. 2008;93:1600-8.

18. Биктагирова ЭМ, Кравцова ОА, Саттарова ЛИ, Вагапова ГР Влияние полиморфизмов генов CTLA-4 и PTPN-22 на риск развития аутоиммунного тиреоидита среди населения республики Татарстан. Медицинская иммунология. 2010;12(1-2):10314. (Biktagirova EM, Kravtsova OA, Sattarova LI, Vagapova GR. Influence of polymorphisms of CTLA-4 and PTPN-22 genes on developmental risk autoimmune thyroiditis among the population of the Republic of Tatarstan. Meditsinskaya Immunologiya. 2010;12(12):103-14).

19. Zhang $\mathrm{M}, \mathrm{Ni} \mathrm{J}, \mathrm{Xu}$ WD. Association of CTLA-4 variants with susceptibility to inflammatory bowel disease: a meta-analysis. Hum Immunol. 2014;75(3): 227-33.

20. Pastuszak-Lewandoska D, Sewerynek E, Domańska D. CTLA-4 gene polymorphisms and their influence on predisposition to autoimmune thyroid diseases (Graves' disease and Hashimoto's thyroiditis). Arch Med Sci. 2012;8(3): 415-21.

21. Lee YH, Choi SJ, Ji JD, Song GG. CTLA-4 and TNF- $\alpha$ promoter-308 A/G polymorphisms and ANCA-associated vasculitis susceptibility: a meta-analysis. Mol Biol Rep. 2012;39(1):319-26

22. Ni J, Qiu LJ, Zhang M. CTLA-4 CT60 (rs3087243) polymorphism and autoimmune thyroid diseases susceptibility: a comprehensive meta-analysis. Endocr Res. 2014;39(4):180-8.

23. Man-Man Lu, Qian-Ling Ye, Chen-Chen Feng. Association of FAS gene polymorphisms with systemic lupus erythematosus: a case- 
control study and meta-analysis. Experimental and Therapeutic Medicine. 2012;4:497-502.

24. Qiu H, Tang W, Yin P, Cheng F, Wang L. Cytotoxic T-lymphocyte associated antigen 4 polymorphism and Hashimoto's thyroiditis susceptibility: a meta-analysis. Endocrine. 2014;45(2):198-205.

25. He H, Jazdzewski K, Li W, Liyanarachchi S, Nagy R, Volinia S, et al The role of microRNA genes in papillary thyroid carcinoma. Proc Natl Acad Sci USA. 2005;102:19075-80.

26. Kochetova OV, Gaynullina MK, Viktorova TV. DIO2, TPO CYP1A1 AND CYP1A2 gene polymorphism in women with thyroid disease. Gig Sanit. 2014; 3: 52-6.

27. Gцzь HI, Цzзelik S, Aloğlu M. Is the TSHR D727E polymorphism a genetic predisposition for multinodular goiter in the Turkish population? Genet Mol Res. 2016;15(3): 385-90.

(Надійшла до редакції 20.08.2019 р.)

\section{Ассоциация полиморфизма генов $B C L-2$, CTLA-4, APO-1/Fas с активностью пролиферации и апоптоза в тиреоидной ткани больных узловыми формами зоба на фоне аутоиммунного тиреоидита и аденомой щитовидной железы}

\author{
М.И. Шеремет ${ }^{1}$, Л.П. Сидорчук' , В.А. Шидловский², \\ А.В. Шидловський ${ }^{2}$, А.Д. Беденюк ${ }^{2}$, Г.С. Курочкин ${ }^{3}$, \\ Н.П. Ткачук' , Я.В. Гырла' \\ 'Буковинский государственный медицинский университет, г. Черновцы, \\ Украина \\ 2Тернопольский государственный медицинский университет \\ им. И.Я. Горбачевского, г. Тернополь, Украина \\ ЗГосударственный университет медицины и фармации им. М. Тестемицану, \\ г. Кишинев, Республика Молдова
}

Резюме. Цель - изучение показателей апоптоза и пролиферативной активности в ткани щитовидной железы (ЩЖ) у больных с узловым зобом на фоне аутоиммунного тиреоидита (УЗАИТ) и аденому щитовидной железы (АЩЖ) по сравнению с морфологически неизмененной тканью, подсчет количества иммунореактивных клеток, экспрессирующих указанные маркеры. Материал и методы. Проводили сравнительный анализ процессов апоптоза и пролиферации в ткани щитовидной железь у больных УЗАИТ и АЩЖ и в морфологически неизмененной ткани щитовидной железы путем исследования экспрессии/ плотности маркеров Fas/FasL, Bcl-2, p53 и Ki-67 на тиреоцитах в участках лимфоидной инфильтрации и их деструкции, а также в морфологически неизмененных участках тиреоидной ткани (контроль). Подсчитывали количество иммунореактивных клеток, экспрессирующих указанные маркеры, с использованием иммуногистохимического метода с учетом полиморфизма генов BCL-2 (rs17759659), CTLA-4 (rs231775) и APO-1/Fas (rs2234767). Peзультаты. Установлено, что у больных УЗАИТ и АЩЖ активируются несколько звеньев программируемого килинга тиреоцитов с преимуществом Fas-индуцированного апоптоза, который ассоциируется с промотором гена BCL-2 (rs17759659) ( $\mathrm{F}=25,33$; p $<0,001)$ и почти в 6 раз слабее - с промотором гена CTLA-4 (rs231775) ( $F=4,23, p=0,017)$ из-за выраженной экспрессии Fas и FasL на поверхности клеток в участках лимфоидной инфильтрации и деструкции тиреоцитов (сильнее у носителей GG генотипа гена BCL-2 - на 18,54\% и 36,18\% соответственно), что свидетельствует об инициации внешнего пути апоптоза через каспазний механизм (эффекторную каспазу 8),

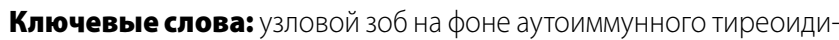
та, аденома щитовидной железы, полиморфизмы APO-1/Fas, CTLA-4 и $B C L-2$ генов.

Association of BCL-2, CTLA-4, APO-1/Fas genes polymorphisms with activity of proliferation and apoptosis in thyroid tissue of patients with nodular forms of goiter combined with autoimmune thyroiditis and thyroid adenoma

\section{M.I. Sheremet', L.P. Sydorchuk', V.O. Shidlovskyi ${ }^{2}$, O.V. Shidlovskyi ${ }^{2}$, A.D. Bedenyuk ${ }^{2}$, G.S. Kurochkin ${ }^{3}$, N.P. Tkachuk' ', Yu.V. Gyrla'}

'Surgery Department, Bukovinian State Medical University, Chernivtsi, Ukraine ${ }^{2}$ Surgery Department, I.Y. Horbachevsky State Medical University, Ternopil, Ukraine

${ }^{3}$ Department of Family Medicine, Genetics Laboratory, State University of Medicine and Pharmacy «Nicolae Testemitanu», Chisinau, Republic Moldova

Abstract. The purpose - to study the indicators of apoptosis and proliferative activity in thyroid tissue (thyroid gland) in patients with nodular goiter on the background of autoimmune thyroiditis (NGAIT) and thyroid adenoma (TA) compared with morphologically unchanged tissue, calculating the number of counts. Material and methods. Conducted a comparative analysis of the processes of apoptosis and proliferation in thyroid tissue in patients with NGAIT and TA and in morphologically unchanged thyroid tissue by investigating the expression / density of markers Fas/FasL, BCl-2, p53 and Ki-67 on thyrocytes in sections of lymphoid and their lymphoid infiltration, as well as in morphologically unchanged areas of thyroid tissue (control) The number of immunoreactive cells expressing these markers was calculated using the immunohistochemical method taking into account the BCL-2 (rs17759659), CTLA-4 (rs231775) and APO-1/Fas (rs2234767) gene polymorphisms. Results. It was found that patients NGAIT and TA activated a few links of programmable several parts are activated programmed thyroid cell killing advantage of Fas-induced apoptosis, which is associated with the promoter of the gene $B C L-2$ ( $r$ 17759659) $(\mathrm{F}=25,33 ; \mathrm{p}<0,001)$ and almost 6 times weaker promoter gene CTLA-4 (rs231775) ( $F=4.23, p=0.017)$, through expression of Fas and FasL on the surface of cells in areas of lymphoid infiltration and destruction of thyroid cells (stronger in carriers of GG genotype of $B C L-2$ gene - by $18.54 \% 36,18 \%$, respectively), indicating that the initiation of the external paths of apoptosis through the activation of caspase mechanism (effector caspase 8).

Keywords: nodular goiter on the background of autoimmune thyroiditis, thyroid adenoma, polymorphisms APO-1/Fas, CTLA-4 and $B C L-2$ genes. 